\title{
ANALISA DAMPAK LINGKUNGAN KERJA FISIK DAN NON FISIK PADA KINERJA KARYAWAN PT. LA NINA NIAGA NASIONAL
}

\author{
*Siti Fatimah ${ }^{1}$, Samsul Hadi ${ }^{2}$ \\ 1,2,Prodi Manajemen, Fakultas Ekonomi dan Bisnis, Universitas Muhammadiyah Surabaya \\ ${ }^{*}$ sitifatimahh2332@gmail.com
}

\begin{tabular}{l}
\hline Informasi Artikel \\
\hline Draft awal: Januari 2021 \\
Revisi : Januari 2021 \\
Diterima : Maret 2021 \\
Available online: Maret 2021 \\
\hline
\end{tabular}

Keywords: Work Environment,

Employee Performance

Tipe Artikel : Research paper

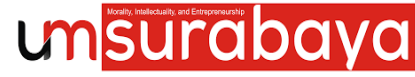

UNIVERSITAS MUHAMMADIYAH SURABAYA

Diterbitkan oleh Universitas

Muhammadiyah Surabaya

\begin{abstract}
A development of business that was increasingly rapid had led to the competition, resulting in each company having to struggle to create new innovations in order to be able to compete in the market. The following research aimed to determine the impact of physical and non-physical work environments on the performance of employees of PT. La Nina Niaga National. The rmethod used a qualitative by collecting observation data, interviews and documentation with data analysis by using Miles ana Huberman. The results showed that the physical work environment at PT. La Nina Niaga Nasional was still in poor condition. Non-physical work environment at PT. La Nina Niaga Nasional in the form of superior ana voluntary relationships, relations between employees. The more conducive the physical and non-physical working conditions were the more employee performance that would be happened.
\end{abstract}

Perkembangan bisnis semakin pesat telah menimbulkan persainga, sehingga setiap perusahaan harus berjuang untuk menciptakan inovasi baru agar dapat bersaing di pasar. Penelitian ini bertujuan mengetahui pengaruh lingkungan kerja fisik dan non fisik terhadap kinerja karyawan PT. La Nina Niaga Nasional. Metode yang digunakan adalah kualitatif dengan pengumpulan data observasi, wawancara, dan dokumentasi dengan analisisi data menggunakan Miles Hubermas. Hasil peneltiian menunjukkan bahwa lingkungan kerja fisik di PT La Lina masih kurang baik. Sedangkan lingkungan kerja non fisik di PT La Lina Niaga Nasional memiliki hubungan yang baik antar karaywan. Semakin kondusif lingkungan fisik dan non fisik dalam lingkungan kerja maka kinerja karyawana akan semakin meningkat.

\section{PENDAHULUAN}

Dimasa revolusi industri 4.0 saat ini Money Changer atau penukaran uang asing sangat diminati oleh berbagai kalangan masyarakat. Perkembangan dunia yang semakin maju dalam bidang ekonomi, bisnis, teknologi dan ilmu pengetahuan menjadikan Money Changer sebagai jasa penukaran uang asing yang pertama kali dipikirkan oleh seseorang yang akan melakukan keperluan bisnis, perdagangan di sektor barang dan keuangan, melanjutkan pendidikan ke luar negeri, liburan atau perjalanan ke luar negeri, berobat ke luar negeri, penyimpanan atau investasi dan lain-lain (Darsono dan Rahman, 2018: 5). Penukaran uang asing ini sekarang sangat mudah ditemukan di daerah pariwisata, bandara, pusat belanja dan perbatasan dua negara (Indah, 2017: 2)

PT. La Nina Niaga Nasional adalah salah satu pedagang atau penukaran valuta asing di Surabaya yang beralamat di Jl Dharmahusada No. 201, Mojo,
Kecamatan Gubeng, Kota Surabaya, Jawa Timur. PT. La Nina Niaga Nasional adalah Perdagangan Valuta Asing (PVA) Berizin sesuai dengan ketentuan Bank Indonesia. PVA bukan bank adalah perusahaan berbadan hukum Perseroan Terbatas yang melakukan kegiatan usaha jual beli uang kertas asing (Darsono dan Rahman, 2018: 97).

Keberhasilan perusahaan menuntut karyawan PT. La Nina Niaga Nasional harus memberikan kemampuan dan potensi terbaik dalam menyelesaikan pekerjaannya. Namun, masih terdapat permasalahan yaitu hilangnya konsentrasi terhadap pekerjaannya, jika ada sesuatu yang membuatnya kehilangan konsentrasi seperti tempat yang bising, penerangan yang kurang, suhu ruangan yang terlalu panas, pertukaran udara yang kurang, peralatan kerja yang tidak mendukung atau suasana kerja yang tidak nyaman maka akan berdampak buruk seperti keterlambatan dalam pelayanan, kesalahan dalam 
perhitungan, kesalahan memberikan mata uang dan lain-lain.

Lingkungan kerja yang kondusif akan memberikan rasa aman dan memungkinkan para karyawan PT. La Nina Niaga Nasional dapat bekerja secara optimal. Selain itu, lingkungan kerja juga dapat mempengaruhi emosi dan semangat bekerja sehingga waktu kerja digunakan secara efektif dan optimis prestasi kerja karyawan juga tinggi (Sudaryo, Aribowo dan Sofiati, 2018: 47). Menurut tabel di atas permasalahan sering terjadi seperti kebisingan yang menyebabkan pegawai merasa emosi dan hilang konsentrasi dalam bekerja dikarenakan lokasi yang termasuk di pusat kota, pencahayaan ruangan yang kurang dan terlalu silau menjadikan kesulitan dalam mengenali fisik US\$ bagus dan US\$ second karena adanya selisih harga yang berbeda, suhu ruangan yang terlalu panas, pemadaman listrik yang akhirnya efisiensi waktu pelayanan menjadi lebih lama karena karyawan harus menghitung jumlah uang secara manual, kesalahan hitung jumlah uang karena pengawasan yang kurang teliti dan ketat, faktor lain dari customer yang membuat konsentrasi kerja karyawan menjadi terganggu. Gangguan koneksi WLAN / Wi-Fi yang menyebabkan tidak dapat input data dalam database, update harga bahkan transaksi internet banking serta adanya pandemi covid-19 yang harus menerapkan protokol kesehatan lebih ketat lagi serta adanya covid-19 orang-orang akan menjaga kesehatan dengan tidak bepergian keluar rumah.

Berdasarkan latar belakang masalah tersebut, maka peneliti tertarik untuk melakukan penelitian dengan judul "Analisa Dampak Lingkungan Kerja Fisik dan Non-Fisik Pada Kinerja Karyawan PT. La Nina Niaga Nasional".

\section{LANDASAN TEORI}

\section{Lingkungan Kerja}

Menurut Sedarmayanti (dalam Sudaryo, Aribowo dan Sofiati, 2018: 47) lingkungan kerja adalah keseluruhan bahan dan alat perkakas yang dihadapi karyawan, lingkungan sekitar, metode pekerjaan, serta pengaturan kerjanya baik secara individu maupun kelompok. Sunyoto (2015: 38) mendefinisikan lingkungan kerja merupakan suatu komponen yang sangat penting untuk karyawan dalam melakukan aktivitas bekerja.

Menurut Sedarmayanti (dalam Sudaryo, Aribowo dan Sofiati, 2018: 47-48), secara garis besar lingkungan kerja terbagi menjadi dua yaitu lingkungan kerja fisik dan lingkungan kerja non fisik.

\section{a. Lingkungan Kerja Fisik}

Semua keadaan yang berbentuk fisik terdapat disekitar tempat bekerja yang dapat mempengaruhi karyawan secara langsung maupun tidak langsung
(Sedarmayanti, 2011: 21). Seperti : kursi, meja, kelembapan, sirkulasi udara, warna, bau tidak sedap, kebisingan dan lain-lain. Langkah pertama untuk memperkecil pengaruh lingkungan fisik maka yang dilakukan adalah harus mempelajari Sumber Daya Manusia, kemudian digunakan sebagai dasar memikirkan lingkungan fisik yang sesuai.

Indikator lingkungan kerja fisik menurut Sudaryo, Aribowo dan Sofiati (2018: 51-59) indikator lingkungan kerja fisik sebagai berikut :

1. Penerangan

Penerangan ruangan sangat penting dalam perusahaan penukaran uang asing karena dengan penerangan yang baik akan mempermudah karyawan dalam mengenali uang asli / palsu, kemudahan dalam ketatabukuan tanpa terganggu oleh bayangan. Penerangan yang baik membantu karyawan melihat dengan cepat, mudah dan senang dalam bekerja.

2. Pewarnaan

Komposisi warna yang tepat dapat menyenangkan bagi karyawan dan memberikan semangat dalam melakukan tugasnya. Keuntungan penggunaan warna yang tepat tidak hanya bersifat keindahan dan psikologis tetapi juga bersifat ekonomis.

3. Kebersihan

Menjaga kebersihan ruangan kerja dapat menjaga kesehatan para karyawan. Lingkungan kerja yang bersih menimbulkan perasaan tenang, sehingga karyawan dapat bekerja dengan sebaikbaiknya.

4. Sirkulasi / Pertukaran Udara

Udara yang segar dan nyaman memiliki komposisi kimia yang bagus, dengan suhu / kelembapan yang tidak mengganggu pernafasan dan kesegaran badan.

5. Kebisingan / Suara

Tujuan dari pengaturan dan pengendalian suara bising dalam ruangan kerja untuk menjaga kepekaan pendengaran para karyawan. Suara bising yang terdengar dapat menghilangkan konsentrasi, cepat mendatangkan lelah, kekesalan yang akan mengakibatkan menurunnya kinerja karyawan. Pemberian musik yang sesuai dengan jenis pekerjaan mampu memberikan efek suasana hati gembira dan mengurangi rasa lelah / ketegangan syaraf dalam bekerja.

6. Keamanan

Pemberian fasilitas keamanan barangbarang dan dalam lingkungan kerja akan memberikan ketenangan pegawai dalam melakukan pekerjaan. 


\section{b. Lingkungan Kerja Non Fisik}

Lingkungan kerja non fisik adalah semua keadaan yang terjadi berkaitan dengan hubungan kerja, baik dengan atasan, bawahan maupun dengan sesama rekan kerja. Menurut Nitisemito (2010: 139) lingkungan kerja non fisik mencerminkan kondisi yang mendukung kerja sama antara tingkat atasan dan bawahan maupun sesama rekan kerja dalam 1. Hubungan atasan dan bawahan

Hubungan atasan dan bawahan terjadi saat atasan memberikan tugas-tugas untuk dikerjakan oleh bawahannya. Penyampaian informasi dari pimpinan ke bawahan bisa meliputi banyak hal seperti tugas, kebijakan organisasi, tujuan yang ingin dicapai dan adanya perubahan kebijakan. Hubungan atau interaksi antara atasan dan bawahan harus dijaga dengan harmonis dan saling menjaga etika, menghargai satu sama lain agar tercipta lingkungan kerja yang nyaman.

2. Hubungan antar karyawan

Hubungan antar karyawan dalam lingkungan kerja di dalam perusahaan merupakan hal yang tidak dapat dipisahkan, karena akan menimbulkan tingkat kepuasan kinerja karyawan. Situasi lingkungan dalam menyelesaikan pekerjaan dan interaksi antar karyawan demi untuk menciptakan kelancaran kerja.

\section{Kinerja Karyawan}

Kinerja diartikan sebagai prestasi yang didapatkan seseorang secara keseluruhan selama periode tertentu dalam melaksanakan tugasnya. Proses pelaksanaan tugas tersebut memiliki standar hasil kerja, target atau sasaran yang telah ditentukan dan disepakati bersama. Kinerja seseorang merupakan kombinasi dari kemampuan, usaha dan kesempatan yang dapat diukur atau dinilai dari hasil kerjanya (Nur'aini, 2017: 12-13).

Menurut Kasmir (2019: 208-210) terdapat enam indikator untuk mengukur kinerja pegawai atau karyawan secara individu yaitu :

1. Kualitas / Mutu

Dilakukan dengan melihat kualitas (mutu) dari pekerjaan yang dihasilkan melalui proses tertentu. Kualitas merupakan suatu hasil penyelesaian pekerjaan dengan tingkat mendekati titik kesempurnaan.

2. Kuantitas / Jumlah

Dilakukan dengan melihat dari kualitas (jumlah) yang dihasilkan karyawan dalam penyelesaian pekerjaan. Kualitas merupakan produksi yang dihasilkan dapat ditunjukkan dalam satuan mata uang, jumlah unit atau jumlah siklus kegiatan yang diselesaikan.

3. Waktu / Jangka Waktu suatu perusahaan. Kondisi yang diciptakan perusahaan terkait dengan lingkungan kerja non fisik meliputi suasana kekeluargaan, komunikasi yang baik antara atasan dan bawahan dan pengendalin diri.

Indikator lingkungan kerja non fisik, menurut Rahmawanti (dalam Kristanti, 2017) pengukuran indikator lingkungan kerja non fisik dari penelitian terdahulu:

Pekerjaan tertentu diberikan batas waktu dalam menyelesaikan pekerjaan. Ada batas waktu minimal dan maksimal yang harus dipenuhi dalam menyelesaikan pekerjaan. Jika melanggar atau tidak memenuhi ketentuan waktu tersebut, maka dianggap kinerjanya kurang baik.

4. Penekanan Biaya

Biaya yang dikeluarkan untuk setiap aktivitas perusahaan sudah dianggarkan sebelum dijalankan. Biaya yang sudah dianggarkan merupakan sebagai acuan agar tidak melebihi batas yang sudah ditentukan. Jika pengeluaran melebihi batas maka akan terjadi pemborosan dan dianggap kinerjanya kurang baik.

5. Pengawasan

Seluruh pekerjaan yang sedang dijalankan perlu melakukan pengawasan, situasi dan kondisi selalu berubah dari keadaan yang baik menjadi tidak baik atau sebaliknya. Oleh karena itu, setiap aktivitas pekerjaan memerlukan pengawasan agar menghasilkan kinerja yang baik.

6. Hubungan Antar Karyawan

Penilaian kerja sering dikaitkan dengan kerja sama atau kerukunan antar karyawan dan antar pimpinan. Hubungan ini diukur apakah seseorang karyawan mampu mengembangkan perasaan saling menghargai, niat baik dan kerja sama dengan karyawan lain untuk menciptakan suasana yang nyaman dan saling mendukung dalam menyelesaikan pekerjaan.

\section{METODE PENELITIAN}

Penelitian ini menggunakan pendekatan deskriptif kualitatif. Penelitian kualitatif merupakan penelitian yang menekankan pada kualitas atau hal terpenting dari sifat suatu barang atau jasa. Penelitian kualitatif dapat didesain untuk memberikan sumbangannya terhadap teori, praktis, kebijakan, masalah-masalah sosial dan tindakan. Penelitian kualitatif dilakukan karena peneliti ingin mengekspor fenomena-fenomena yang tidak dikualifikasikan yang bersifat deskripsi seperti proses suatu langkah kerja, formula suatu resep, pengertian tentang suatu konsep, yang beragam, karakteristik barang atau jasa, gambar, gaya, tata cara budaya dan lain sebagainya (Satori dan Komariah, 2017: 22-23). Jenis data yang digunakan dalam penelitian ini adalah data primer dan data sekunder. Teknik pengambilan sampel yang 
dilakukan peneliti dalam penelitian ini adalah menggunakan snowball Sampling. Snowball yaitu peneliti menentukan informan tanpa menentukan jumlah secara pasti dan peneliti akan menggali informasi secara terus menerus terkait topik penelitian yang dibutuhkan, pencarian informan akan selesai apabila yang dibutuhkan peneliti sudah dianggap memadai (Fatihudin, 2015: 78). Metode pengumpulan data yang digunakan dalam penelitian ini adalah observasi, wawancara dan dokumentasi.

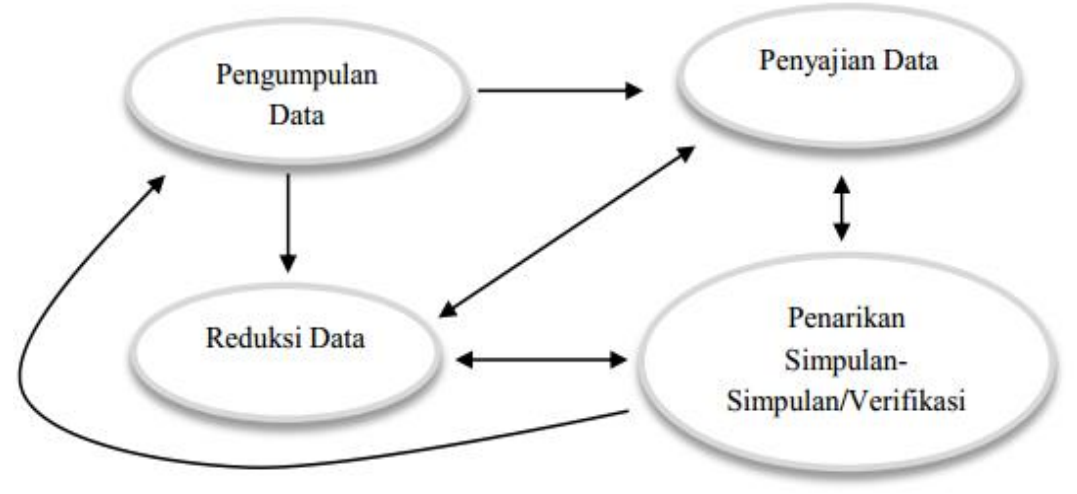

Gambar 1. Komponen Analisis Data : Model Interaktif

Sumber: Miles dan Huberman (dalam Hardani dkk, 2020:174)

\section{PEMBAHASAN}

\section{Lingkungan kerja fisik pada PT. La Nina Niaga} Nasional

Beberapa temuan lingkungan kerja fisik pada PT. La Nina Niaga Nasional sebagai berikut :

1) Karyawan pada PT. La Nina Niaga Nasional sudah mengetahui dan memahami definisi dari lingkungan kerja fisik adalah segala sesuatu, kondisi atau peralatan seperti mesin hitung, udara, teman bekerja yang berada di sekitar tempat bekerja, dan secara langsung maupun tidak langsung dapat membantu mempercepat serta mempermudah pekerjaan sehari-hari. Lingkungan kerja yang kondusif akan mempengaruhi kinerja karyawan dan membantu dalam mencapai tujuan perusahaan.

2) Mengenai keadaan lingkungan kerja fisik di PT. La Nina Niaga Nasional masih dalam keadaan baik meskipun terkadang masih ada kendala seperti pemadaman listrik dan lain-lain, jika ada yang kurang memadai maka perusahaan akan berusaha mengatasi kendala tersebut guna memberikan kenyamanan para karyawan dan pelanggan jika berada di area PT. La Nina Niaga Nasional.

3) Lingkungan kerja fisik yang ada di PT. La Nina Niaga Nasional terdiri dari lingkungan kerja fisik langsung seperti meja, kursi, alat tulis, alat hitung uang, komputer dan lain-lain. Sedangkan untuk lingkungan kerja fisik tidak langsung seperti penerangan, kebisingan, keamanan, pewarnaan, aroma atau bau-bauan ruangan, kebersihan dan lain-lain.

4) Karena PT. La Nina Niaga Nasional termasuk perusahaan dibidang keuangan maka lingkungan sangat mempengaruhi hasil kerja karyawan, jika kinerja karyawan turun pasti akan menimbulkan banyak kesalahan, pekerjaan jadi terhambat dan itu dapat berakibat perusahaan rugi. Lingkungan kerja fisik adalah bagian komponen yang sangat penting untuk karyawan melakukan aktifitas kerjanya (Sunyoto, 2015: 38).

Dapat diketahui bahwa semakin positif nilai lingkungan kerja fisik tersebut dilaksanakan oleh setiap karyawan PT. La Nina Niaga Nasional, maka akan semakin berdampak baik pada kinerja karyawan.

\section{Lingkungan kerja non fisik di PT. La Nina Niaga Nasional}

Berdasarkan wawancara terhadap informan W1, W2 dan W3 dari pengaruh lingkungan kerja fisik pada PT. La Nina Niaga Nasional maka akan dibahas sebagai berikut :

1) Karyawan pada PT. La Nina Niaga Nasional sudah mengetahui dan memahami definisi dari lingkungan kerja non fisik adalah keadaan yang menyangkut psikis, tidak bisa dilihat dengan panca indra namun bisa dirasakan. Lingkungan kerja non fisik mencerminkan hubungan atasan dan bawahan atau hubungan antar karyawan.

2) Hubungan atasan dan bawahan serta hubungan antar karyawan di PT. La Nina Niaga Nasional 
terjalin dengan baik, saling komunikasi, saling bekerja sama, saling memberikan semangat dan saling membantu satu dengan yang lainnya. Meskipun terkadang adanya perbedaan pendapat namun hal seperti itu dianggap wajar dan cepat diselesaikan hari itu juga agar keesokan harinya tidak ada rasa dendam.

3) Adanya lingkungan kerja non fisik dapat memberikan dampak terhadap kinerja karyawan. Saat karyawan melakukan pekerjaan dengan saling bekerja sama maka pekerjaan akan lebih cepat, lebih teliti, lebih dapat mempermudah. Harmonisnya hubungan atasan dan bawahan serta hubungan antar karyawan memberikan efek kenyamanan dan kebahagiaan karyawan selama bekerja seperti yang telah dinyatakan oleh informan W3.

Demikian dapat diketahui bahwa semakin positif nilai lingkungan kerja non fisik tersebut dilaksanakan oleh setiap karyawan pada PT. La Nina Niaga Nasional, maka akan semakin berdampak baik pada kinerja karyawan.

\section{Kinerja Karyawan pada PT. La Nina Niaga Nasional}

Kinerja adalah sebuah keluaran dari suatu proses baik secara kualitas maupun kuantitas yang dicapai oleh seorang karyawan dari hasil perpaduan atau interaksi antara kemampuan, motivasi dan kesempatan dalam dalam melaksanakan tugas sesuai dengan tanggung jawab yang telah diberikan. Semakin tinggi pencapaian kinerja karyawan maka akan berdampak pada perusahaan. Berdasarkan wawancara W1, W2 dan W3 dari kinerja karyawan PT. La Nina Niaga Nasional maka akan dibahas sebagai berikut :

1. Tahun 2018 ke 2019 kinerja karyawan PT. La Nina Niaga Nasional mengalami peningkatan dan ditahun 2020 adanya penurunan drastis dari tahun sebelumnya. Kinerja karyawan disebut juga prestasi kerja karyawan yang sesuai dengan tujuan perusahaan. Prestasi kerja karyawan sangat beragam karena perusahaan memiliki tujuan dan harapan yang berbeda-beda. PT. La Nina Niaga Nasional kinerja karyawan diukur dari seberapa bisa seorang karyawan mampu mencapai target penjualan. Data penjualan dari tahun 2018 - 2019 pencapaian karyawan mengalami peningkatan dibandingkan tahun 2020.

2. Penerapan reward pada perusahaan PT. La Nina Niaga Nasional belum terlaksana secara maksimal. Belum ada penerapan untuk memberi reward terhadap karywan yang kinerjanya melebihi target. Reward adalah balas jasa atas kerja karyawan yang melebihi target yang telah ditentukan perusahaan. Reward bisdsnys diberikan berupa insentif atau gaji tambahan yang sesuai dengan prestasi kerja karyawan tersebut. Pemberian reward sangat memberikan nilai positif terhadap karyawan dan perusahan. Karyawan yang mendapatkan reward akan selalu semangat dan termotivasi untuk menjalankan pekerjaan sehari-hari.

3. Karyawan mendapatkan teguran saat melakukan kesalahan. Karyawan diminta selalu jujur dan bertanggung jawab atas pekerjaannya. Karena perusahaan di dalam bidang keuangan. Maka karyawan diminta selalu hati-hati dalam bekerja agar tidak melakukan kesalahan yang fatal.

Berdasarkan pemaparan mengenai kinerja karyawan di PT. La Nina Niaga Nasional lebih mengutamakan pelayanan pelanggan dan ketelitian dalam bekerja. tidak ada target khusus namun jika target terlalu tinggi diadakan tour gratis bersamasama untuk karyawan dan keluarganya.

\section{Dampak Lingkungan Kerja Fisik dan Non Fisik Pada Kinerja Karyawan PT. La Nina Niaga Nasional.}

Lingkungan kerja fisik dan non fisik merupakan hal yang penting guna mewujudkan peningkatan kinerja karyawan pada PT. La Nina Niaga Nasional. Lingkungan kerja fisik dan non fisik yang kondusif akan memberikan rasa aman dan memungkinkan para karyawan dapat bekerja secara optimal. Selain itu, lingkungan kerja fisik dan non fisik juga dapat mempengaruhi emosi dan semangat bekerja sehingga waktu kerja digunakan secara efektif, optimis, prestasi kerja dan kinerja karyawan juga tinggi.

Adanya perhatian pada lingkungan kerja fisik dan non fisik dapat meningkatkan kinerja karyawan apabila kedua hal tersebut dapat berjalan seimbang. Apabila lingkungan kerja fisik di PT. La Nina Niaga Nasional tidak maksimal akan menurunkan motivasi kerja para karyawan, begitu juga dengan lingkungan kerja non fisik yang tidak baik akan mengganggu kinerja dan akan mempunyai kecurigaan buruk terhadap para karyawan. Agar tidak terjadi hal tersebut maka perlu solusi-solusi yang sebagaimana diungkapkan oleh informan W1, W2 dan W3. Diharapkan agar tidak timbul dampak yang buruk dan sisi negatif atau like and dislike antar atasan dan bawahan atau antar sesama karyawan serta dapat meningkatkan kinerja para karyawan pada PT. La Nina Niaga Nasional. Sebagaimana yang telah diungkapkan oleh Soelistya (2017: 57) bahwa teori McGregor tahun 1960 hubungan atasan dengan karyawan dapat dilihat dari sudut pandang yang berbeda yaitu teori X dan Y yaitu sisi negatif dan sisi positif. Sesuai dengan hasil penelitian Noorainy (2017) bahwa dalam lingkungan kerja non fisik harus 
membina hubungan yang baik antara sesama rekan kerja, bawahan maupun atasan perlu dilakukan karena saling membutuhkan dan hal tersebut menjadi peran penting karena hubungan kerja yang terbentuk sangat mempengaruhi psikologis karyawan. Sependapat dengan hasil penelitian Pratiwi, et al., (2017) untuk meningkatkan kinerja karyawan yang efektif dan efisien perlu penerapan lingkungan kerja yang baik dan situasi yang nyaman bagi karyawan.

Akan tetapi hasil penelitian berikut bertolak belakang dengan hasil penelitian Damopolii, et al., (2018) bahwa lingkungan kerja tidak berpengaruh terhadap kinerja karyawan. Peningkatan atau penurunan kinerja karyawan tidak dipengaruhi oleh perubahan lingkungan kerja, karena lingkungan kerja yang kondusif tidak bisa tercipta apabila budaya organisasi yang dimiliki tidak mendukung pada PT. PLN Persero Area Manado.

Berdasarkan pemaparan hasil wawancara informan W1, W2 dan W3 bahwa lingkungan kerja fisik dan non fisik pada PT. La Nina Niaga Nasional sudah cukup baik meskipun terkadang masih ada kendala ataupun perbedaan pendapat antar atasan dan bawahan. Adanya kendala dalam lingkungan kerja fisik dan non fisik di perusahaan sebenarnya sudah diketahui dan disadari oleh keamanan berpengaruh terhadap kinerja karyawan. Hal tersebut ditunjukkan dengan hasil wawancara informan W1, W2, W3 dan hasil observasi bahwa mereka sependapat jika lingkungan kerja fisik dalam kondisi kurang baik dan dapat mempengaruhi terhadap kinerja karyawan.

\section{SIMPULAN DAN SARAN}

\section{Simpulan}

Berdasarkan hasil penelitian dan pembahasan maka bisa diperoleh kesimpulan sebagai berikut :

1. Lingkungan kerja fisik pada PT. La Nina Niaga Nasional yang merupakan penerangan, pewarnaan, kebersihan, sirkulasi udara, kebisingan, dan keamanan berpengaruh terhadap kinerja karyawan. Hal tersebut ditunjukkan dengan hasil wawancara informan W1, W2, W3 dan hasil observasi bahwa mereka sependapat jika lingkungan kerja fisik dalam kondisi kurang baik dan dapat mempengaruhi terhadap kinerja karyawan.

2. Lingkungan kerja non fisik pada PT. La Nina Niaga Nasional yang merupakan hubungan antar karyawan, hubungan karyawan dengan atasan dalam kondisi harmonis dan saling bekerjasama. Hal ini ditunjukkan dengan hasil wawancara informan W1, W2, W3 dan hasil observasi bahwa semakin baik hubungan atasan dan karyawan serta hubungan antar karyawan akan semakin meningkatkan kecepatan kerja dan ketelitian dalam bekerja.

3. Kinerja karyawan PT. La Nina Niaga Nasional terdapat penurunan dalam 3 tahun terakhir yakni ditahun 2020. Berbagai kendala dalam lingkungan kerja fisik dan non fisik serta kondisi covid-19 memberikan dampak terhadap kinerja para karyawan.

4. Lingkungan kerja fisik dan non fisik yang tidak kondusif dapat berdampak pada kinerja karyawan PT. La Nina Niaga Nasional. Informan W1, W2 dan W3 menyatakan jika ada dampak yang diberikan dari lingkungan kerja fisik dan non fisik, karena hal tersebut saling mendukung saat mengerjakan suatu pekerjaan sehari-hari.

\section{Saran}

Untuk perusahaan

1. Untuk memaksimalkan kondisi lingkungan kerja fisik merupakan bentuk upaya yang harus dilakukan perusahaan sehingga karyawan termotivasi untuk meningkatkan kinerja yang lebih baik untuk mencapainya tujuan perusahaan. Disarankan menambah genset untuk membantu dalam kelancaran bekerja saat adanya pemadaman listrik, penambahan lampu penerangan di ruangan kerja teller dan penambahan AC agar suhu ruangan tidak terlalu panas. Karena sekarang ada pandemi covid-19 disarankan menyediakan tempat cuci tangan di depan kantor PT. La Nina Niaga Nasional.

2. Untuk menjaga kondisi lingkungan non fisik tetap seimbang maka perusahaan harus melakukan upaya menjaga hubungan harmonis antar karyawan, karyawan dengan atasan. Disarankan contohnya memberikan reward kepada karyawan yang kinerjanya sangat baik atau mengadakan kegiatan diluar urusan pekerjaan seperti liburan bersama, maka akan menjaga keharmonisan hubungan antar karyawan, karyawan dengan atasan sehingga kinerja para karyawan tetap terjaga dengan baik.

3. Lingkungan kerja fisik dan non fisik harus dikontrol secara berkala apabila mengalami kendala maka harus segera didapatkan solusi agar kinerja karyawan tidak mengalami penurunan. Lingkungan kerja fisik dan non fisik merupakan hal yang sangat penting untuk meningkatkan kinerja karyawan agar tercapainya tujuan perusahaan.

\section{Untuk Penelitian Selanjutnya}

1. Sebagai pertimbangan penelitian selanjutnya dalam meningkatkan kinerja karyawan PT. La Nina Niaga Nasional perlu diteliti dengan variabel seperti kemampuan dan skill, 
pengetahuan, rancangan kerja, kepribadian, motivasi kerja, gaya kepemimpinan, budaya organisasi, kepuasan kerja, loyalitas, komitmen, dan disiplin kerja. Jika berminat melakukan penelitian dengan topik yang sama, disarankan untuk memilih responden yang lebih berdominasi oleh laki-laki dan memilih tempat penelitian pada jenis perusahaan manukfaktur ataupun instansi pemerintah sehingga dapat memberikan hasil yang lebih bervariasi dan diharapkan lebih baik dari penelitian sebelumnya

\section{DAFTAR PUSTAKA}

Anshori, M., \& Iswati, S. (2009). Buku Ajar Metodologi Penelitian Kuantitatif. Surabaya: Airlangga University Press.

Arikunto, S. (2010). Prosedur Penelitian: Suatu Pendekatan Praktik. Jakarta: Rineka Cipta.

Busro, M. (2018). Teori-Teori Manajemen Sumber Daya Manusia. Jakarta: Perdanamedia Group.

Damopolii, Y. J., Lengkong, V. P., \& Walangitan, M. D. (2018). Pengaruh Lingkungan Kerja, Konflik Peran dan Stres Kerja Terhadap Kinerja Karyawan Pada PT. PLN Persero Area Manado. Jurnal EMBA, 6(3): 16681677.

Darsono, R., \& Rahma, E. (2018). Pasar Valuta Asing: Teori dan Praktik. Depok: Kharisma Putra Utama Offset.

Dessler, G. (2015). Manajemen Sumberdaya Manusia. Jakarta: Salemba Empat.

Fatihudin, D. (2015). Metodologi Penelitian untuk Ilmu Ekonomi, Manajemen dan Akuntansi. Sidoarjo: Zifatama Publisher.

Hardani, Auliya, N., Andriani, H., Fardani, R., Ustiawaty, J., Utami, E., et al. (2020). Metode PenelitianKualitatif dan Kuantitatif. Yogyakarta: CV. Pustaka Ilmu Group Yogyakarta.

Hasibuan, M. S. (2019). Manajemen Sumber Daya Manusia. Jakarta: PT Bumi Aksara.

Hery. (2019). Manajemen Kinerja. Jakarta: PT Grasido.

Indah, P. (2017). Forex : Raih Untung di Pasar Valuta Asing : Panduan untuk Pemula. Bandung: Putra Danayu Publisher.
Kasmir. (2019). Manajemen Sumber Daya Manusia (Teori dan Praktik). Jakarta: PT Raja Grafindo Persada.

Kristanti, E. (2017). Pengaruh Lingkungan Kerja Fisik dan Lingkungan Kerja Non Fisik Terhadap Stres Kerja dan Dampaknya Terhadap Kinerja (Studi Pada Kantor Bersama Samsat Mojokerto Kota). Ilmu Manajemen, Volume 5 Nomor 1.

Mahudi. (2013). Manajemen kinerja Sektor Publik. Yogyakarta: UPP AMP YKPN.

Mangkunegara, A. (2013). Manajemen Sumber Daya Manusia Perusahaan. Bandung: PT Remaja Rosdakarya.

Moehariono. (2009). Pengukuran Kinerja Berbasis Kompetisi. Bogor: Ghalia Indonesia.

Moleong, L. (2017). Metode Penelitian Kualitatif. Bandung: PT. Remaja Rosdakarya Offset.

Nitisemito, A. (2000). Manajemen Personalia. Jakarta: Ghalia Indonesia.

Noorainy, F. (2017). Pengaruh Lingkungan Kerja Fisik dan Non Fisik Terhadap Kinerja Pegawai Pada Sekretariat Daerah Kabupaten Pangandaran. Journal of Management Review, 2(1):75-85.

Nur'aini DF, F. (2017). Paduan Praktis Evaluasi Kinerja Karyawan. Yogyakarta: Quadrant.

Pratiwi, D., Lie, D., Efendi, \& Chandra, E. (2017). Pengaruh Disiplin Kerja dan Lingkungan Kerja Terhadap Kinerja Pegawai Pada PT Bank Sumut Syariah Cabang Pematangsiantar. Jurnal MAKER, 3(1): 7381.

Sarwono, P. (2015). Landasan Psikologi Proses Pendidikan. Jakarta: Bumi Aksara.

Satori, D., \& Komariah, A. (2017). Metodologi Penelitian Kualitatif. Bandung: Afabeta.

Sedarmayanti. (2011). Manajemen Sumber Daya Manusia . Yogyakarta: STIE YKPN.

Sedarnayanti. (2009). Pengembangan Kepribadian Pegawai . Bandung: Mandar Maju.

Soelistya, D. (2017). Membangun Komitmen Karyawan. Sidoarjo: Nizamial Learning Center.

Sudaryo, Y., Aribowo, A., \& Sofiati, N. A. (2018). Manajemen Sumberdaya Manusia, Kompensasi Tidak Langsung dan Lingkungan Kerja Fisik. Yogyakarta: CV Andi Offset. 
Fatimah, Hadi

Sugiyono. (2015). Metode Penelitian Kuantitatif, Sunyoto, D. (2015). Penelitian Sumber Daya Kualitatif dan R\&D. Bandung: Afabeta.

Manusia (Teori, Kuesioner, Alat Statistik dan

Sugiyono. (2018). Metode Penelitian Kualitatif. Contoh Riset). Yogyakarta: Caps Publishing. Bandung: Elfabeta. 